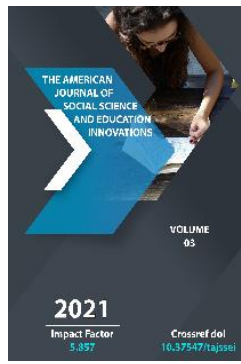

\title{
Prorositive Meaning And Its Expression In Syntactic Units
}

\author{
Huriniso Sharapovna Usmonova
}

Doctor Of Philological Sciences, Professor, Namangan State University, Uzbekistan

Journal Website:

http://usajournalshub.c om/index,php/tajssei

Copyright: Original content from this work may be used under the terms of the creative commons attributes 4.0 licence.

\section{ABSTRACT}

This article analyzes the relationship between language and thought, speech and the expression of proposition in it. Thoughts on the role of the relational predicate in the expression of the proposition are stated.

\section{KEYWORDS}

Language, thinking, consciousness, proposition, relational structure, speech, speech process, language codes, relational predicate.

\section{INTRODUCTION}

Any speech process is the process of expressing one's thoughts about the objective world using language codes (signs). Therefore, speech is connected with the objective world through the mind. A certain part of the objective world is reflected in the human mind, and the generalized images of the members of this reflected being are expressed through the use of language codes.

It seems that language and thinking are inextricably linked. In the human brain, 
consciousness and language are two relatively independent aspects. Each of them has a memory in which specific knowledge is stored and the means to activate them. These tools act by extracting from the memory of the two types of knowledge shown what is needed to narrate a particular event [2]. Thus, these two aspects are so closely intertwined that the activity of the mind always follows the activity of language and forms a unique and complex process of verbal thinking according to its content.

Consciousness is a set of human knowledge about the world around him. Man acquires such knowledge not only through the process of direct observation of the universe, but also by obtaining information from others. Therefore, human cognitive activity cannot take place without the help of the language system.

The basic knowledge stored in the "memory" of language is the knowledge of the word and its meanings. The means of activating this knowledge are grammatical means.

The selection of the necessary words in the speech process and their introduction directly into the speech is based on the pre-existing knowledge of the speaker about the word.

Any speech process requires two stages: the first stage (formation of thought), the second stage (the emergence of thought through material means for the purpose of communication).

In the first stage of the process of verbal thinking, the activated elements of consciousness are divided into separate frames, and each of them reflects a separate event or phenomena. The means of dividing the flow of thought into individual frames are relational predicates and their concrete meanings. Proposition arises from the combination of relational predicates and their meanings [2.6].

The concept of proposition is widely used in modern linguistics to represent an objective reality expressed through a specific syntactic device.

Although any sentence represents a certain proposition, but not every proposition must be represented by a sentence. From this it is clear that proposition is concerned with the content side of speech, and that the concepts of proposition and speech are not equal.

The proposition differs from the sentence, first of all, in terms of its content. For if speech is recognized as a whole consisting of a relation of form and content, the propositive structure is considered to belong to only one side of its semantic structure. At the same time, proposition also differs from speech in that a particular event represents a relation of objects that are logically equal to each other. For example: 1) Aziz lent money to his brother; 2) He borrowed money from his brother Aziz; 3) The money was borrowed from Aziz by his brother.

All of the above represents a common event, a proposition, involving the same participants. Their participants are Aziz and his brother and the money relation between them. The reason why this story is expressed in different sentences is that in one place Aziz is taken as a base, in the second place his brother is taken, and in the third place money is taken. For example, the phrase Anwar handed a flower to Rano (A.Qodiriy) forms a syntactic paradigm by expressing a proposition with expressions such as Rano received a flower from Anwar, Anwar received a flower for Rano. The means of 
uniting the members of the paradigm is the propositive meaning. All three sentences have the same propositive structure: S-subject agens + subject patsiens + (predicate) P. It can be seen from the above examples that the formal structure differs from the propositive structure.

The relational predicate plays an important role in the expression of the proposition. Some linguists liken the relational predicate to a drilled board. Just as the holes drilled in the board are covered with wooden nails, relational predicates also have certain voids, empty cells. Filling such gaps in relational predicates creates a proposition. For example, the relational predicate of lending, which is the basis for the formation of the above sentences, has three empty spaces - an empty cell: a) the lender; b) the borrower and c) the value of the loan or the loan instrument (what the debt is). As a result of filling these empty cells with concrete lexical units, the three-digit predicate is transformed into a proposition.

Thus, although relational predicates with a certain number of spaces are important for expressing a proposition, this predicate itself is not sufficient for a proposition. In order for a predicate to move into a propositional expression, it will have to fill in its blanks with appropriate lexical units. Hence, as a result of the expansion of the composition, the relational predicate reveals its valences, and all of them together pass into the expression of a certain proposition.

The role of syntactic members in a sentence is not limited to which member is related to which member. For example, the sentences He read the Book and the Book was read by him were composed of the same words. These words are used interchangeably in both sentences and form the same 'tree of subordination'. But the above statements differ in that the same words occupy different syntactic positions. In the first sentence it is used in the possessive position, in the complementary position of the object to which the action falls, in the second sentence it is used in the complementary position of the subject (s) performing the action, and in the possessive position of the object receiving the action. Thus, not only from what words the members involved in the syntactic device are expressed, but also in what syntactic position (situation) these members come from is important for the semantic structure of the sentence. Because even though two or more sentences have in common that they consist of the same words, the fact that these words occur in different situations ensures that these sentences are different. Hence, in such places, the main differential sign of a sentence is not the material aspect of the members involved in the sentence, but the sign of their position.

It seems that the substantial (material) aspect of the members that make up a sentence is just as important for the sentence as the position of these members.

This shows that it is not enough to name the parts of a sentence correctly in order for the content of the sentence to correspond to the objective being it represents. It is also necessary to accurately express the relationship between them.

It should be noted that the choice of certain words by the speaker to express this or that information takes place only after the syntactic construction necessary for the correct expression of a certain objective reality, a certain syntactic situation is selected. Therefore, E. Kurilovich emphasizes that 
syntactic meaning is primary in relation to lexical meaning [3.179].

In the process of speaking activity, along with the selection of the syntactic device, the word is also chosen to fill this device. Both of these processes are inextricably linked to the nomination process. That is why V.G. Gak said: "Word and syntactic device perform nominative and organizational functions at different levels in the process of sentence construction" [1.54]. This suggests that not only words but also sentence patterns can be studied in a nominative aspect.

According to the approach to sentence construction in terms of word combinations, speech is considered as a combination of nominative units - words and phrases. From the point of view of semantic syntax, the participants of the speech are studied as an action (situation). Participants are referred to as "actants". Thus, the functions of the semantic participants of the sentence - the actants - in the syntactic connection of these actants are not the same. Therefore, the study of the relationship between content participants and the syntactic situations they occupy also began to attract the attention of syntax experts in the following period. As a result, special attention began to be paid to the study of the relationship between form and content of speech in semantic syntax.

\section{REFERENCES}

1. Гак В.Г. Проблемы лексикограмматической организации предложения: Автореф. дисс. ... А-ра филол. наук. - М., 1967. - С.54

2. Кацнельсон С.Д. Речомыслительные процессы // ВЯ. 1984. № 4 с.6
3. Курилович Е. Очерки по лингвистике. М., 1962. - C.179.

4. Сайфуллаева Р. Хозирги ўзбек тилида гап бўлакларининг семантикаси ва грамматикаси. - Т.: Фан, 2000.

5. Сайфуллаева Р. Хозирги ўзбек адабий тили формал- функционал талқинда. Қўшма гап. - Т.: Фан, 1993.- 3086.

6. Сайфуллаева Р. Хозирги уузбек адабий тилида қўшма гапларнинг шаклвазифавий (формал-функционал) талқини: Филол. фанлари д-ри ... дис. автореф. -Т., 1993. -48 б.

7. Шахобиддинова Ш. Грамматик маъно талқини хусусида: Филол. фанлари номзоди... дис. автореф. -Самарқанд, 1993. -246.

8. 8. Қурбонова М.М. Бош бўлаклар талқинига доир. - Т.: Университет нашриёти, 1998.-15б.

9. Қурбонова $M$ ва бошқалар. Ўзбек тилининг структурал синтаксиси: Ўқув қўлланма. - Т.: Ўзбекистон миллий ун-ти, 2004. - 1446. 